\section{Comparative study of metadiscourse markers in ELT textbooks and Iranian localized high school English textbooks}

\section{Bagherfard, Forouzan}

English Department, Najafabad Branch, Islamic Azad University, Najafabad, Iran (forouzan_bagherfard@yahoo.com)

Simin, Shahla $\bowtie$

Farhangian University, Iran

(shahlasimin@yahoo.com)

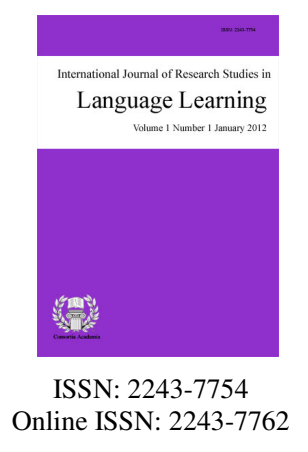

OPEN ACCESS

\begin{tabular}{lll}
$\begin{array}{l}\text { Received: } 25 \text { September } 2016 \\
\text { Available Online: } 1 \text { November } 2016\end{array}$ & Revised: 3 October 2016 & Accepted: 17 October 2016 \\
\hline
\end{tabular}

\title{
Abstract
}

The present study attempted to investigate the use of interactive and interactional metadiscourse markers in two commonly ELT textbooks in Iran, namely, Iranian high school English textbooks, compared with the American English File series. To achieve the purpose of this study, all the reading sections in high school textbooks, Book 3 and Book 4 were selected. To have an equal amount of data in four textbooks, the first 6769 words in American English File Books 3 and 4 and 6769 words in high school English Books 3 and 4 were considered. To ensure the equality of the level of difficulty, the Flesch's (1948) readability formula was employed. According to Hyland (2005) model, interactive and interactional metadiscourse markers were identified in reading sections of these four textbooks. The descriptive analysis of the study revealed that interactional metadiscourse markers were used more in American English File series, however, interactive ones were applied more in Iranian high school textbooks. The findings showed that there were significant differences in the case of code glosses and evidentials in two series of textbooks. The use of code glosses in Iranian high school textbooks was higher than the other corpus, whereas evidentials were used more than the other interactive markers in American English File series. The results of chi-square analysis indicated that there were significant differences between two textbooks series in terms of using interactional markers. But there were not significant differences in applying the interactive ones. Among different categories of interactional metadiscourse markers, engagement markers were used more than other interactional markers in the Iranian high school textbooks and self-mentions applied more in American English File series. The findings of this study have some useful implications for teachers, curriculum designers, and material developers.

Keywords: metadiscourse makers; interactive metadiscourse markers; interactional metadiscourse markers; Iranian high school textbooks; American English File series 


\section{Comparative study of metadiscourse markers in ELT textbooks and Iranian localized high school English textbooks}

\section{Introduction}

Since the need for English language learning has been increased in today's life, the process of developing materials for English as foreign language (EFL) has gained importance. According to Tomlinson (2001) language learning materials can be defined as "anything which is used by teachers and learners to facilitate the learning of language" (p. 66). Therefore, any source of input such as the Internet, textbooks, videos and live talks which are used for the process of language could be called language learning materials (Tomlinson, 2003; Waters, 2009). Among various types of materials, textbooks are the most important and useful instructional material to be employed in language classroom (Richards, 2001). Indeed, textbooks can be regarded as the most crucial elements of any language programs. According to Zohrabi, Sabouri, and Kheradmand (2014) "textbooks are one of the elements that may promote or discourage learners depending on their materials. They are a kind of support for both teachers and learners. Textbooks provide students a kind of consistency" (p. 95). Textbooks give appropriate input to L2 learners to practice and are mostly viewed as reliable sources of ideas for amateur teachers to plan and teach lessons in their classrooms (McDonough \&Show, 2003; Richards, 2001).

With regard to the significance of textbooks as an indispensable part of English language teaching, evaluating them seems to be necessary. Littlejohn (2011) states that "materials analysis and evaluation enable us to look inside the materials and to take more control over their design and use" (p. 183). MacGrath (2002) believes that textbooks evaluation is an important value for the development and administration of language learning programs. The influence of textbooks and the main role that they play in the process of language learning around the world have conducted many researches on the effectiveness of materials and on how development of materials can benefit from the research findings in the realm of second language acquisition, discourse analysis conversational analysis and corpus analysis (Richards, 2006; Taki, 2004, Talebinejad \& Namdar, 2011).

Discourse analysis is a discipline that covers the analysis of social, cultural and educational aspects of language and it also deals with of language larger than sentence (Alba-Juez, 2009). Discourse analysis provides an adequate means in order to engage in the descriptive analysis and comparison of written texts. Discourse analysis that concentrates on the analysis of written and spoken texts and development of written and spoken discourse led to creation of metadiscourse.

Metadiscourse is considered as a novel concept in the fields of discourse analysis and language education which refers to linguistic elements in a text which used to organize a discourse or the writer's attitudes towards either its content or the reader (Hyland, 2000). It also refers to the relationship between writers of the texts and their texts as well as authors of texts and their readers (Hyland, 2005). Different definitions and classifications on metadiscourse have been proposed by different scholars (Vande Kopple, 2002; Thompson, 2003; Adel, 2006). Vande Kopple (2002) defines metadiscourse as the elements in texts that transfer meaning other than those that are primarily referential. According to Thompson (2003), metadiscourse refers to "language in text which talks about the text rather than propositional content" (p. 6). In Adel's (2006) words, "metadiscourse is discourse about evolving discourse, or the writer's explicit commentary on her own ongoing text" (p. 2). The most comprehensive idea seems to have expressed by Hyland (2005) who considers metadiscourse as a phenomenon, which is distinct from propositional meaning and shows the personalities, attitudes and assumptions about communicators.

In fact, Metadiscourse is one of the main means which allows the writers to engage the readers in the text and it also makes the text more comprehensible and understandable for the readers in the way the writer intended. 
Comparative of metadiscourse markers in ELT textbooks and Iranian localized high school English textbooks

Thus, metadiscourse is believed to be an important feature of communication. Lack of metadiscourse markers would make text much less personal, less interesting and difficult to follow. Therefore, research on the way metadiscourse markers are used, can help to understand the meaning of this markers and familiarize with the usage of these markers.

The importance of metadiscourse in teaching and learning language lies in the fact those students should be familiarized with metadiscourse because learning metadiscourse help them know that language has various functions and there is different possible interaction in different situations. Consequently, it is expected that material developers and textbooks planner provide appropriate metadiscoursal features in different disciplines for special kinds of texts and special kinds of addresses to make favorable effect on their readers.

In Iran two main types of English Language Teaching (ELT) textbooks are used to teach English. One is public school textbooks which are developed by Ministry of Education of Iran. The other books are produced by western publishers such as Longman, Oxford, and Cambridge which are taught by English language institutes. Therefore, in order to select appropriate textbook that achieves the needs of the learners and teaching/learning requirements, the textbook evaluation is required. Many studies have been conducted on different aspects of ELT textbooks evaluation (Alavinia \& Siyadat, 2013; Riazi \& Mosallanejad, 2010; Jahangard, 2007), but little has been done on the use of metadiscourse in these textbooks. Thus, it is necessary to study metadiscourse markers in ELT textbooks to specify the importance of these markers in these textbooks. Considering the vital role that ELT textbooks play in EFL classes and the role of metadiscourse markers in developing relation with reader, this study aimed at examining two ELT textbooks, namely, Iranian high school textbooks and American English File series in terms of using metadiscourse markers and to find out any statistically significant difference in terms of using interactive and interactional metadiscourse markers in these two ELT textbooks The findings of the study will be helpful for materials developers, curriculum designers, researchers, and Curriculum Development Center of the Ministry of Education because they must be aware of strengths and weaknesses of the materials in order to remove the weakness in the future textbook versions. Therefore, the results of such study can be fruitful to EFL learners and teachers. This study can also be useful in textbook selection and adaptation in EFL contexts in order to satisfy the needs and requirement of language programs. In line with the mentioned research objectives, the following research questions are addressed in this study:

$>\quad$ What is the frequency of metadiscourse markers used in the reading sections of Iranian high school textbooks and American English File series?

$>\quad$ Are there any significant differences between the reading sections of Iranian high school textbooks and American English File series in terms of frequency of the use of interactional and interactive metadiscourse markers?

According to the research questions, the following research null hypothesis was formulated:

$>\quad \mathrm{H} 01$. There are not any significant differences between the reading sections Iranian high school textbooks and American English File series in terms of frequency of interactional and interactive metadiscourse markers.

\section{Method}

\subsection{Corpus of the Study}

The corpus of this study included the reading sections of two locally-produced ELT textbooks (two English textbooks used in Iranian high schools), and the internationally-produced ELT textbooks (American English Files). Regarding the high school English textbooks, it was decided to investigate English Books 3 and 4 because of the level and length of the reading passages. As for American English File book series, Books 3 and 4 were selected because of the level of difficulty and number of words they correspond to high school English Books 3 and 4. There are six reading sections in Book 3 (Birjandi, Nowroozi, \& Mahmoodi, 2013) and eight reading sections in Book 4 (Birjandi, Ananisarab, \& Samimi, 2013). Book 4 has been used as a pre- university textbook 
Bagherfard, F., \& Simin, S.

and now the system of education has changed and the 'pre-university' is named $4^{\text {th }}$ Grade. In American English File series (Oxendan \& Lathman-koening, second edition), each book has nine reading sections. To have an equal amount of data in both textbooks the first 6769 words from American English File Books 3 and 4 and the first 6769 words from high school English Books 3 and 4 were analyzed. Felsch's (1948) Readability Formula was used to determine the difficulty level of the reading sections.

\subsection{Research Instrument}

For the purpose of the current study, Hyland's (2005) classification of metadiscourse markers was employed. The reason for choosing this model was that it is a comprehensive, explicit and clear-cut enough model of metadiscourse. The following table draws on Hyland's (2005) model of metadiscourse markers:

Table 1

Interpersonal Model of Hyland (2005)

\begin{tabular}{|c|c|c|}
\hline Category & Function & Examples \\
\hline Interactive & $\begin{array}{l}\text { Help to guide the reader through } \\
\text { the text }\end{array}$ & resources \\
\hline Transitions & $\begin{array}{l}\text { Express relation between main } \\
\text { clauses }\end{array}$ & In addition; but; thus; and \\
\hline Frame markers & $\begin{array}{l}\text { Refers to discourse acts, } \\
\text { sequences, or stages }\end{array}$ & Finally, to conclude, my purpose is \\
\hline Endophoric markers & $\begin{array}{l}\text { Refer to information in other } \\
\text { parts of the text }\end{array}$ & Noted above, see figure, in section 2 \\
\hline Evidential & $\begin{array}{l}\text { Refer to information from other } \\
\text { text }\end{array}$ & According to $\mathrm{X}, \mathrm{Z}$ states \\
\hline Code glosses & $\begin{array}{l}\text { Elaborate propositional } \\
\text { meanings }\end{array}$ & Namely, e.g., such as, in other words \\
\hline Interactional & Involve the reader in the text & resources \\
\hline Boosters & $\begin{array}{l}\text { Emphasize certainty or close } \\
\text { dialogue }\end{array}$ & in fact, definitely, it is clear that \\
\hline Attitude markers & $\begin{array}{l}\text { Express writer's attitude to } \\
\text { proposition }\end{array}$ & $\begin{array}{l}\text { Unfortunately, I agree, surprisingly } \\
\text { I, me, my, our }\end{array}$ \\
\hline Self-mentions & Explicit reference to author & Might, perhaps, possible, about \\
\hline Hedges & $\begin{array}{l}\text { Withhold commitment and open } \\
\text { dialogue }\end{array}$ & Consider, note, you can see that \\
\hline Engagement markers & $\begin{array}{l}\text { Explicitly build relationship with } \\
\text { readers }\end{array}$ & \\
\hline
\end{tabular}

\subsection{Procedure}

With regard to the nature of the study and the research questions, the reading sections of the two ELT textbooks were obtained. To make the comparison possible, texts should have been equal in terms of the number of words or length of the texts and their level of difficulty. Therefore, the readability of all the texts was determined by the use of Flesch's Readability Formula to guarantee that the texts had similar difficulty levels. Since the texts in the Iranian high school textbooks in comparison to the texts in internationally developed English textbooks were not equal with regard to the density of texts, it was decided to calculate the frequency of metadiscourse markers in the first 6769 words in American English File Books 3 and 4 and the first 6769 words in high school English Books 3 and 4.

To reach the purpose of the study, the reading sections of two ELT textbooks were carefully read word by word with specific attention to the functions and meanings of the words in order to find out the interactive and interactional metadiscourse markers based on Hyland (2005) model. The metadiscourse markers were manually counted in each corpus. In order to ensure that analysis was reliable, the researcher used intra-rater and 
Comparative of metadiscourse markers in ELT textbooks and Iranian localized high school English textbooks inter-rater reliability. All the data was analyzed twice with a two-week time interval to avoid any mistakes in detecting and counting the number of metadiscourse markers in the whole corpus. The degree of consistency in the two analysis attempts was found to be $95.5 \%$. In another occasion, inter- rater reliability was examined; the correlation between the researcher's counts and a second rater's (an expert who assisted the researcher) counts was calculated. The agreement was $96.3 \%$, which is a high level of correlation.

\subsection{Data Analysis}

To answer the research questions raised in this study, SPSS (Statistical Package for Social Sciences) version 22 was employed for statistical analyses and the non-parametric statistical test of chi-square was run in order to find out the differences among the subcategories of metadiscourse in both textbook series.

\section{Results}

\subsection{Descriptive Analysis}

Metadiscourse Used by Four Corpora - In Table 2, the number of the total words as well as the number of metadiscourse markers in Iranian high school textbooks and American English File series are shown.

Table 2

Frequencies and Percentages of the metadiscourse Markers in Iranian High School English Textbooks and American English File Series

\begin{tabular}{|c|c|c|c|c|c|c|c|}
\hline \multirow{2}{*}{ Book } & \multirow{2}{*}{ Group } & \multicolumn{2}{|c|}{ Metadiscourse } & \multicolumn{2}{|c|}{ The other Words } & \multicolumn{2}{|c|}{ Total Words } \\
\hline & & Frequency & percentage & Frequency & percentage & Frequency & percentage \\
\hline \multirow{3}{*}{ Book3 } & High & 202 & 11.2 & 1608 & 88.8 & 1810 & 100.0 \\
\hline & School & & & & & & \\
\hline & $\begin{array}{l}\text { American } \\
\text { File }\end{array}$ & 349 & 19.3 & 1461 & 80.7 & 1810 & 100.0 \\
\hline \multirow{3}{*}{ Book4 } & High & 673 & 13.6 & 4286 & 86.4 & 4959 & 100.0 \\
\hline & School & & & & & & \\
\hline & $\begin{array}{l}\text { American } \\
\text { File }\end{array}$ & 623 & 12.6 & 4336 & 87.4 & 4959 & 100.0 \\
\hline \multirow{3}{*}{ Total } & High & 875 & 12.9 & 5894 & 87.1 & 6769 & 100.0 \\
\hline & School & & & & & & \\
\hline & $\begin{array}{l}\text { American } \\
\text { File }\end{array}$ & 972 & 14.4 & 5797 & 85.6 & 6769 & 100.0 \\
\hline
\end{tabular}

As shown in Table 2, among 1810 words, the number of metadiscourse markers in English Book 3 was $(\mathrm{N}=202 ; 11 / 2 \%)$ and that of American English File Book 3 was $(\mathrm{N}=349 ; 19 / 3 \%)$. This table also shows that among 4959 words, in English Book 4 the number of metadiscourse markers was $(\mathrm{N}=673 ; 13.6 \%)$ and in American English File Book 4 was $(\mathrm{N}=623 ; 12.6)$. Also, based on this table, Iranian authors used $(\mathrm{N}=875 ; 12.9 \%)$ metadiscourse markers, while English authors used $(\mathrm{N}=972 ; 14.4 \%)$.

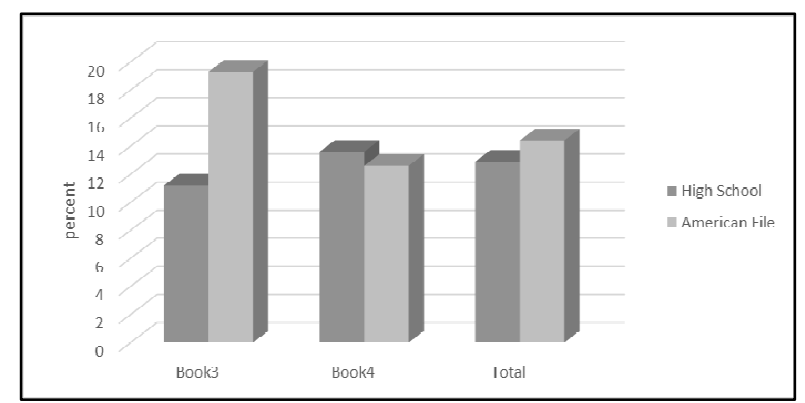

Figure 1. The graphical representation of the percentage of metadiscourse for each textbook 
Bagherfard, F., \& Simin, S.

Descriptive Analysis of Interactive metadiscourse in Iranian High School Textbooks - In Table 3, the results of descriptive statistics of interactive metadiscourse in Iranian high school textbooks are shown.

Table 3

Distribution of Interactive Metadiscourse in Iranian High school Textbooks

\begin{tabular}{|c|c|c|c|c|c|c|c|c|c|c|c|c|}
\hline & \multicolumn{2}{|c|}{ Transition } & \multicolumn{2}{|c|}{$\begin{array}{l}\text { Frame } \\
\text { marker }\end{array}$} & \multicolumn{2}{|c|}{ Endophoric } & \multicolumn{2}{|c|}{ Evidential } & \multicolumn{2}{|c|}{$\begin{array}{c}\text { Code } \\
\text { Glosses }\end{array}$} & \multicolumn{2}{|c|}{ Total } \\
\hline & $\mathrm{F}$ & $\mathrm{P}$ & $\mathrm{F}$ & $\mathrm{P}$ & $F$ & $P$ & $F$ & $P$ & $\mathrm{~F}$ & $P$ & $\mathrm{~F}$ & $P$ \\
\hline Book 3 & 88 & 71.5 & 17 & 13.8 & 0 & 0.0 & 6 & 4.9 & 12 & 9.8 & 123 & 100.0 \\
\hline Book 4 & 296 & 81.5 & 26 & 7.2 & 1 & 0.3 & 2 & 0.6 & 38 & 10.5 & 363 & 100.0 \\
\hline Total & 384 & 79.0 & 43 & 8.8 & 1 & 0.2 & 8 & 1.6 & 50 & 10.3 & 486 & 100.0 \\
\hline
\end{tabular}

Based on Table 3, transitions were the most frequent interactive markers. They consisted of (71.5\%) of the whole instances of metadiscourse markers used in English Book 3. There were 17 instances of frame markers (13.8\%) and 12 instances of code glosses (9.8\%). Finally, evidentials (4.9\%) were the least frequent metadiscourse markers in this textbook. In English Book 4, transitions (81.5\%) were the most used categories of interactive metadiscourse markers. There were 296 instances of transition metadiscourse markers in this book. In addition, there were 38 code glosses $(10.5 \%)$ and 26 frame markers $(7.2 \%)$ in this textbooks. Moreover, there were 2 instances of evidentials. The endophoric was the least interactive metadiscourse marker feature found in English Book 4. Finally, among total interactive markers of these two high school textbooks, the highest percentage belonged to transition markers (79.0\%). Code glosses were the second most frequent markers $(10.3 \%)$, followed by $(8.8 \%)$ frame markers, and $(1.6 \%)$ evidentials. Then, the lowest percentage related to endophoric $(0.2 \%)$.

Descriptive Analysis of Interactive metadiscourse in American English File Series - In Table 4, the results of descriptive statistics of interactive metadiscourse in American English File series will be presented.

\section{Table 4}

Distribution of the Interactive metadiscourse in American English File Series

\begin{tabular}{|c|c|c|c|c|c|c|c|c|c|c|c|c|}
\hline & \multicolumn{2}{|c|}{ Transition } & \multicolumn{2}{|c|}{$\begin{array}{l}\text { Frame } \\
\text { marker }\end{array}$} & \multicolumn{2}{|c|}{ Endophoric } & \multicolumn{2}{|c|}{ Evidential } & \multicolumn{2}{|c|}{$\begin{array}{c}\text { Code } \\
\text { Glosses }\end{array}$} & \multicolumn{2}{|c|}{ Total } \\
\hline & $\mathrm{F}$ & $\mathrm{P}$ & $\mathrm{F}$ & $\mathrm{P}$ & $F$ & $\mathrm{P}$ & $\mathrm{F}$ & $\mathrm{P}$ & $\mathrm{F}$ & $\mathrm{P}$ & $\mathrm{F}$ & $\mathrm{P}$ \\
\hline Book 3 & 133 & 85.3 & 16 & 10.3 & 0 & 0.0 & 1 & 0.6 & 6 & 3.8 & 156 & 100.0 \\
\hline Book 4 & 227 & 73.0 & 34 & 10.9 & 1 & 0.3 & 25 & 8.0 & 24 & 7.7 & 311 & 100.0 \\
\hline Total & 360 & 77.1 & 50 & 10.7 & 1 & 0.2 & 26 & 5.6 & 30 & 6.4 & 467 & 100.0 \\
\hline
\end{tabular}

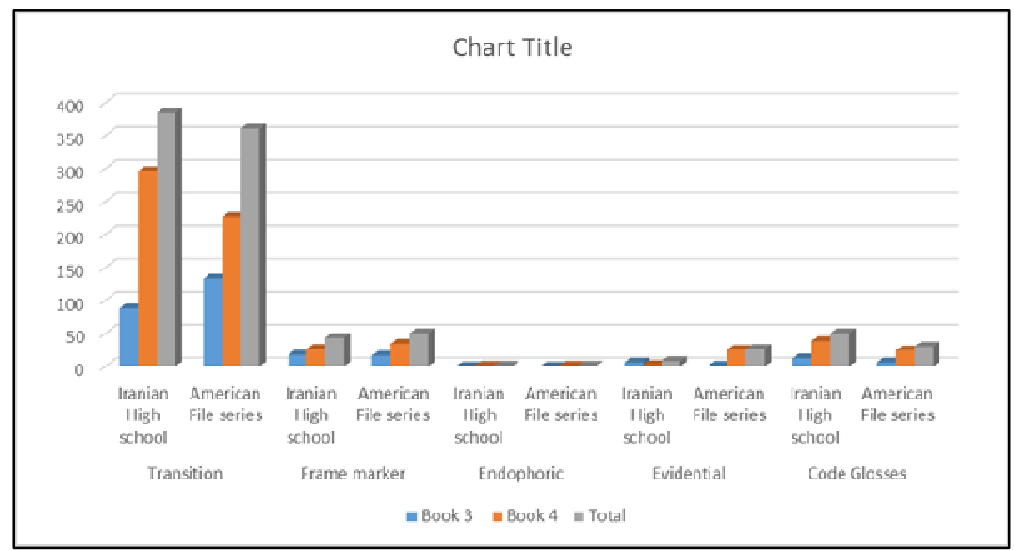

Figure 2. The graphical representation of the frequency of interactives in two textbook series

As seen in the above Table, transitions were the most frequent interactive markers used in American English 
Comparative of metadiscourse markers in ELT textbooks and Iranian localized high school English textbooks

File Book 3. They consisted of $(85.3 \%)$ of the whole instances of metadiscourse markers in this book. There were 16 instances of frame markers $(10.3 \%)$ and 6 instances of code glosses (3.8\%). Finally, the least frequent metadiscourse markers were endophoric (0.3\%). In American English File Book 4, transitions (73.0\%) were the most used categories of interactive metadiscourse markers. In addition, the number of frame markers in American English File Book 4 was (10.9\%). Moreover, there were 25 evidentials (8.0\%) and 24 code glosses (7. 7\%). Finally, endophoric was the least interactive marker found in American English File Book 4. Among total interactive markers used in American File Books 3 and 4, the highest percentage belonged to transition markers $(77.1 \%)$. Frame markers were the second most frequent markers $(10.7 \%)$, followed by $(6.4 \%)$ code glosses, and $(5.6 \%)$ evidentials. Then, the lowest percentage related to endophoric $(0.2 \%)$.

Descriptive Analysis of Interactional metadiscourse in Iranian High School Textbooks - In Table 5, the results of descriptive analysis of interactional metadiscourse in Iranian high school textbooks are presented.

Table 5

Distribution of Interactional metadiscourse in Iranian High school Textbooks

\begin{tabular}{|c|c|c|c|c|c|c|c|c|c|c|c|c|}
\hline & \multicolumn{2}{|c|}{ Hedges } & \multicolumn{2}{|c|}{ Booster } & \multicolumn{2}{|c|}{$\begin{array}{c}\text { Attitude } \\
\text { marker }\end{array}$} & \multicolumn{2}{|c|}{ Self-Mention } & \multicolumn{2}{|c|}{$\begin{array}{l}\text { Engagement } \\
\text { marker }\end{array}$} & \multicolumn{2}{|c|}{ Total } \\
\hline & $\mathrm{F}$ & $\mathrm{P}$ & $\mathrm{F}$ & $\mathrm{P}$ & $\mathrm{F}$ & $\mathrm{P}$ & $\mathrm{F}$ & $\mathrm{P}$ & $\mathrm{F}$ & $\mathrm{P}$ & $\mathrm{F}$ & $\mathrm{P}$ \\
\hline Book 3 & 18 & 22.8 & 16 & 20.3 & 11 & 13.9 & 1 & 1.3 & 33 & 41.8 & 79 & 100.0 \\
\hline Book 4 & 97 & 31.3 & 32 & 10.3 & 16 & 5.2 & 1 & 0.3 & 164 & 52.9 & 310 & 100.0 \\
\hline Total & 115 & 29.6 & 48 & 12.3 & 27 & 6.9 & 1 & 0.3 & 197 & 50.6 & 389 & 100.0 \\
\hline
\end{tabular}

Considering the results in Table 5, engagement markers with (42.3\%) were the most frequent interactional markers used in English Book 3. Hedges were the second most frequent markers (22.8\%), followed by (20.3\%) boosters, and (13.9\%) attitude markers. Finally, self-mention (1.3\%) was the least frequent metadiscourse in this textbook. In English Book 4, engagement markers were the most used categories of interactional markers. In addition, the number of hedges in American English File Book 4 was 97 (31.3\%). Moreover, there were 32 boosters $(10.3 \%)$ and 16 attitude markers $(5.2 \%)$. Finally, self-mention with $(0.3 \%)$ had the lowest percentage. Among, total interactional markers of two high school textbooks, the highest percentage belonged to engagement markers $(50.6 \%)$. Hedges were the second most frequent markers $(29.6 \%)$, followed by $(12.3 \%)$ boosters, and $(6.9 \%)$ attitude markers. The lowest percentage related to self-mention $(0.3 \%)$.

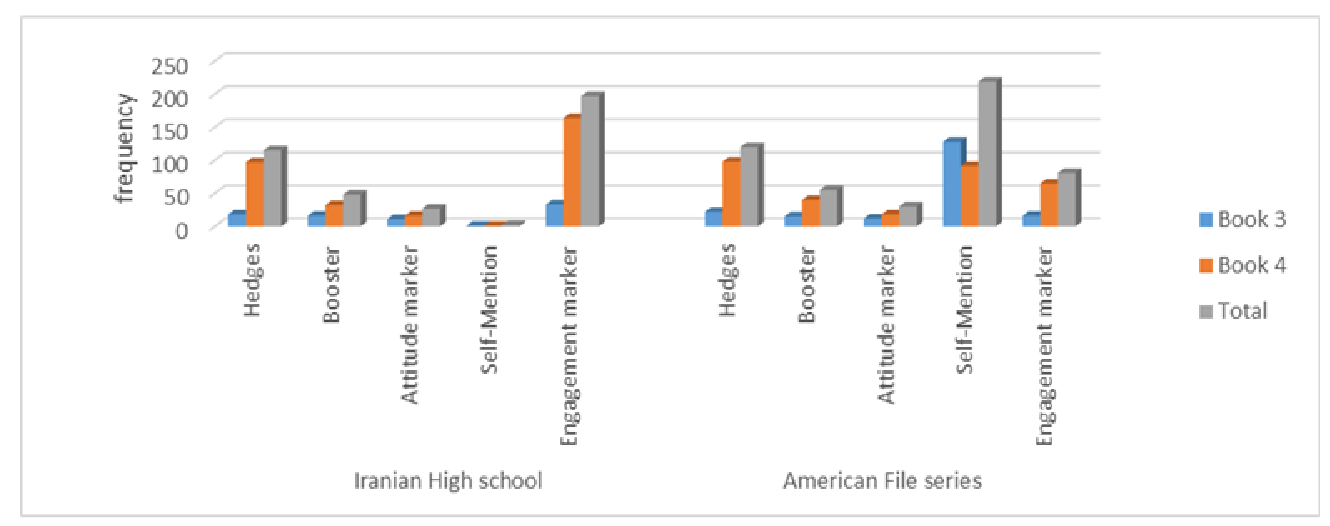

Figure 3. The graphical representation of the frequency of interactional markers in two textbooks series

Interactional metadiscourse in American English File Series - Table 6 reports the frequencies and percentages of the interactional metadiscourse markers in American English File Books 3 and 4.

According to Table 6, self-mentions with $(66.3 \%)$ were found to be the most frequent interactional markers in American English File Book 3. There were 22 instances of hedges (11.4\%) and 16 instances of engagement markers (8.3\%) in this book. The number of engagement markers in American English File Book 3 was 16 
Bagherfard, F., \& Simin, S.

(8.3\%). The attitude markers were found to be the least frequent markers in these textbooks. In American English File Book 4, however, hedges (31.4\%) were the most used categories of interactional markers. There were 91 instances of self-mentions (29.2\%) and 65 instances of engagement markers (20.8\%) in Book 4. Furthermore, the number of boosters was $40(12.8 \%)$. The lowest percentage belonged to the attitude markers (5.8\%). Among total interactional markers used in American English File Books 3 and 4, the highest percentage related to self-mention (43.4\%). Hedges were the second most frequent markers (23.8\%), followed by $(16.0 \%)$ engagement markers, and $(10.6 \%)$ boosters. Then, the lowest percentage was related to attitude markers.

Table 6

Distribution of Interactional metadiscourse in American English File

\begin{tabular}{|c|c|c|c|c|c|c|c|c|c|c|c|c|}
\hline & \multicolumn{2}{|c|}{ Hedges } & \multicolumn{2}{|c|}{ Booster } & \multicolumn{2}{|c|}{$\begin{array}{l}\text { Attitude } \\
\text { marker }\end{array}$} & \multicolumn{2}{|c|}{ Self-Mention } & \multicolumn{2}{|c|}{$\begin{array}{l}\text { Engagement } \\
\text { marker }\end{array}$} & \multicolumn{2}{|c|}{ Total } \\
\hline & $\mathrm{F}$ & $\mathrm{P}$ & $\mathrm{F}$ & $\mathrm{P}$ & $\mathrm{F}$ & $\mathrm{P}$ & $\mathrm{F}$ & $\mathrm{P}$ & $\mathrm{F}$ & $\mathrm{P}$ & $\mathrm{F}$ & $\mathrm{P}$ \\
\hline Book 3 & 22 & 11.4 & 15 & 7.8 & 12 & 6.2 & 128 & 66.3 & 16 & 8.3 & 193 & 100.0 \\
\hline Book 4 & 98 & 31.4 & 40 & 12.8 & 18 & 5.8 & 91 & 29.2 & 65 & 20.8 & 312 & 100.0 \\
\hline Total & 120 & 23.8 & 55 & 10.9 & 30 & 5.9 & 219 & 43.4 & 81 & 16.0 & 505 & 100.0 \\
\hline
\end{tabular}

Interactive and Interactional metadiscourse Markers in Two Textbook Series - In Table 7, the results of descriptive statistics of interactive and interactional metadiscourse markers in Iranian high school textbooks and American English File Books 3 and will be presented.

Table 7

Distribution of Interactive and Interactional metadiscourse in Four Textbook Series

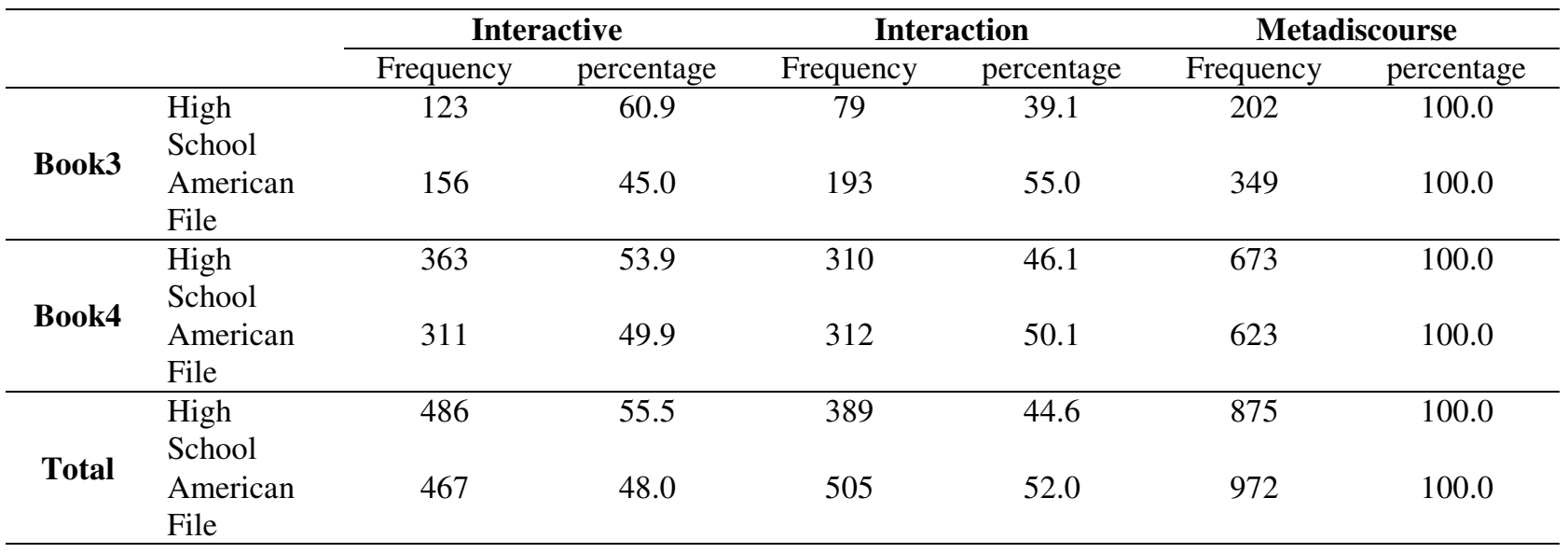

According to Table 7, among the whole counted metadiscourse markers in four textbook series, the interactive metadiscourse markers with $(55.6 \%)$ were employed more frequently than interactional ones with (44.4\%) in English Book 3 and 4. While, interactional metadiscourse markers with (52/0\%) were used more than interactive ones (48.0\%) in American English File Books 3 and 4.

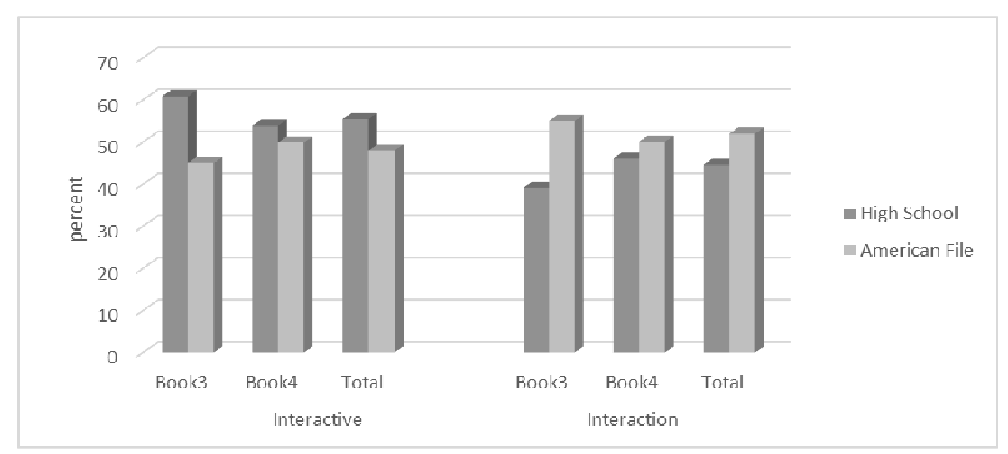

Figure 4. The graphical representation of interactive and interactional metadiscourse in two textbook series 


\subsection{Inferential Analysis}

Analysis of the Second Research Question - In this part of chapter, the second research question will be answered and hypothesis will be tested. According to analysis of tables, the results will be reported and explained.

\section{Research Question 2}

The second research question addressed the differences between the reading sections of Iranian high school textbooks and American English File series in terms of using interactive and interactional metadiscourse markers. To answer this question, one hypothesis was formulated which will be examined in this section.

Hypothesis 1: There are not any significant differences between the reading sections of Iranian high school textbooks and American English File series in terms of using interactive and interactional metadiscourse markers. In order to answer the research question, chi-square test was employed and the results are shown in Table 8.

Table 8

Chi-square Test for Interactive Markers in Four Textbooks

\begin{tabular}{|c|c|c|c|c|c|c|c|c|}
\hline Book & & & Observed $\mathrm{N}$ & Expected N & Residual & Chi-Square & df & Asymp. Sig. \\
\hline \multirow{3}{*}{ Book3 } & High School & & 123 & 139.5 & -16.5 & 3.903 & 1 & .048 \\
\hline & American File & & 156 & 139.5 & 16.5 & & & \\
\hline & & Total & 279 & & & & & \\
\hline \multirow{3}{*}{ Book4 } & High School & & 363 & 337.0 & 26.0 & 4.012 & 1 & .045 \\
\hline & American File & & 311 & 337.0 & -26.0 & & & \\
\hline & & Total & 674 & & & & & \\
\hline \multirow{3}{*}{ Total } & High School & & 486 & 476.5 & 9.5 & .379 & 1 & .538 \\
\hline & American File & & 467 & 476.5 & -9.5 & & & \\
\hline & & Total & 953 & & & & & \\
\hline
\end{tabular}

The results of chi-square test in Table 8 revealed that there was a statistically significant difference between English Book 3 and American English File Book 3 in the use of interactive markers $\left(\chi^{2}=3.903, \mathrm{df}=1, p<0.05\right)$. In fact, it was observed that frequency of occurrence of interactive markers in the reading sections taken extracted from American English Book 3 was much higher than that of it counterpart, i.e., the English Book 3. Based on the results, obtained in Table 4.7, there was significance difference between English Book 4 and American English Book 4 in terms of using interactive metadiscourse markers $\left(\chi^{2}=4.012, \mathrm{df}=1, p<0.05\right)$. It was revealed that interactive markers in the reading sections of English Book 4 was much higher than American File Book 4 much high than American File Book 4. According to this table, no statistically significant value was obtained among Iranian high school Book 3 and 4 and American English File Book 3 and 4 in terms of using interactive markers.

Table 9

Chi-square Test for Interactional metadiscourse Markers in Four Textbooks

\begin{tabular}{|c|c|c|c|c|c|c|c|c|}
\hline Book & & & Observed N & Expected $\mathrm{N}$ & Residual & Chi-Square & df & Asymp. Sig. \\
\hline \multirow{3}{*}{ Book3 } & High School & & 79 & 136.0 & -57.0 & 47.779 & 1 & $<.001$ \\
\hline & American File & & 193 & 136.0 & 57.0 & & & \\
\hline & & Total & 272 & & & & & \\
\hline \multirow{3}{*}{ Book4 } & High School & & 310 & 311.0 & -1.0 & .006 & 1 & .936 \\
\hline & American File & & 312 & 311.0 & 1.0 & & & \\
\hline & & Total & 622 & & & & & \\
\hline \multirow{3}{*}{ Total } & High School & & 389 & 447.0 & -58.0 & 15.051 & 1 & $<.001$ \\
\hline & American File & & 505 & 447.0 & 58.0 & & & \\
\hline & & Total & 894 & & & & & \\
\hline
\end{tabular}

Chi-square reported in Table 9 showed that there was a significant difference between English Book 3 and 
Bagherfard, F., \& Simin, S.

American English File Book 3 in terms of using interactional metadiscourse markers $\left(\chi^{2}=47.779, \mathrm{df}=1, p<0.001\right)$. The use of interactional metadiscourse in American English File Book 3 was significantly more than English Book 3. As it could be observed in the above table, there was no significant difference between English Book 4 and American English File Book 4 with respect to the frequency of interactional metadiscourse markers occurring in their reading section $\left(\chi^{2}=0.006, \mathrm{df}=1, p>0.05\right)$. According to this table, there was significant difference between two textbook series and the occurrence of interactional markers in the reading sections of American English File series was much higher than Iranian English high school textbooks.

\section{Table 10}

Chi-square Test for Different Types of Interactive metadiscourse in English Book 3and American English File 3

\begin{tabular}{|c|c|c|c|c|c|c|c|c|}
\hline Book & & & Observed N & Expected N & Residual & Chi-Square & df & Asymp. Sig. \\
\hline \multirow{3}{*}{ Transition } & High School & & 88 & 110.5 & -22.5 & 9.163 & 1 & .002 \\
\hline & American File & & 133 & 110.5 & 22.5 & & & \\
\hline & & Total & 221 & & & & & \\
\hline \multirow{3}{*}{$\begin{array}{l}\text { Frame } \\
\text { Marker }\end{array}$} & High School & & 17 & 16.5 & .5 & .030 & 1 & .862 \\
\hline & American File & & 16 & 16.5 & -.5 & & & \\
\hline & & Total & 33 & & & & & \\
\hline \multirow{3}{*}{ Endophoric } & High School & & 0 & --- & --- & --- & --- & --- \\
\hline & American File & & 0 & --- & --- & & & \\
\hline & & Total & 0 & & & & & \\
\hline \multirow{3}{*}{ Evidential } & High School & & 6 & 3.5 & 2.5 & 3.571 & 1 & .059 \\
\hline & American File & & 1 & 3.5 & -2.5 & & & \\
\hline & & Total & 7 & & & & & \\
\hline \multirow{3}{*}{$\begin{array}{c}\text { Code } \\
\text { Glosses }\end{array}$} & High School & & 12 & 9.0 & 3.0 & 2.000 & 1 & .157 \\
\hline & American File & & 6 & 9.0 & -3.0 & & & \\
\hline & & Total & 18 & & & & & \\
\hline
\end{tabular}

According to Table 10, among different types of interactive markers in English Book 3 and American English File Book 3, only significant difference was observed in the use transitions. The contrastive comparison between two corpora revealed that transitions were used significantly greater in the American English File Book 3. However, there was not any remarkable difference in the use of frame markers $\left(\chi^{2}=0.030, \mathrm{df}=1, p>0.05\right)$, evidentials $\left(\chi^{2}=3.571, \mathrm{df}=1, p>0.05\right)$, and code glosses $\left(\chi^{2}=2.00, \mathrm{df}=1, p>.005\right)$ in two corpora. The use of endophoric was not observed in any of two textbook series.

\section{Table 11}

Chi-square Test for Different Types of Interactive Markers in English Book 4 and American English Book 4

\begin{tabular}{|c|c|c|c|c|c|c|c|c|}
\hline Book & & & Observed N & Expected N & Residual & Chi-Square & df & Asymp. Sig. \\
\hline \multirow{3}{*}{ Transition } & High School & & 296 & 261.5 & 34.5 & 9.103 & 1 & .003 \\
\hline & American File & & 227 & 261.5 & -34.5 & & & \\
\hline & & Total & 523 & & & & & \\
\hline \multirow{3}{*}{$\begin{array}{l}\text { Frame } \\
\text { Marker }\end{array}$} & High School & & 26 & 30.0 & -4.0 & 1.067 & 1 & .302 \\
\hline & American File & & 34 & 30.0 & 4.0 & & & \\
\hline & & Total & 60 & & & & & \\
\hline \multirow{3}{*}{ Endophoric } & High School & & 1 & 1.0 & .0 & .000 & 1 & 1.000 \\
\hline & American File & & 1 & 1.0 & .0 & & & \\
\hline & & Total & 2 & & & & & \\
\hline \multirow{3}{*}{ Evidential } & High School & & 2 & 13.5 & -11.5 & 19.593 & 1 & $<.001$ \\
\hline & American File & & 25 & 13.5 & 11.5 & & & \\
\hline & & Total & 27 & & & & & \\
\hline \multirow{3}{*}{$\begin{array}{c}\text { Code } \\
\text { Glosses }\end{array}$} & High School & & 38 & 31.0 & 7.0 & 3.161 & 1 & .075 \\
\hline & American File & & 24 & 31.0 & -7.0 & & & \\
\hline & & Total & 62 & & & & & \\
\hline
\end{tabular}

Based Table 11, there were significant differences in the use of evidential and transition markers among 
Comparative of metadiscourse markers in ELT textbooks and Iranian localized high school English textbooks different types of interactive metadiscourse markers in English Book 4 and American English File Book 4. As could be observed from the table, the findings provide support for statistically significant difference in the proportion of evidentials in reading sections of American English File $4\left(\chi^{2}=19.593\right.$, df $\left.=1, p<0.001\right)$. According to this table, there was not any considerable difference in the use of frame markers $\left(\chi^{2}=1.067\right.$, $\left.\mathrm{df}=1, p>0.05\right)$, endophoric $\left(\chi^{2}=0.00, \mathrm{df}=1, p>0.05\right)$, code glosses $\left(\chi^{2}=3.161, \mathrm{df}=1, p>0.05\right)$. While, there was a significant difference in the use of transitions $\left(\chi^{2}=9.103, \mathrm{df}=1, p>0.05\right)$ in English Book 4 than that its counterpart.

Table 12

Chi-square Test for Different Types of Interactive metadiscourse in Four Textbooks

\begin{tabular}{|c|c|c|c|c|c|c|c|}
\hline Book & & Observed N & Expected N & Residual & Chi-Square & $\mathrm{df}$ & Asymp. Sig. \\
\hline \multirow{3}{*}{ Transition } & High School & 384 & 372.0 & 12.0 & .774 & 1 & .379 \\
\hline & American File & 360 & 372.0 & -12.0 & & & \\
\hline & Total & 744 & & & & & \\
\hline \multirow{3}{*}{$\begin{array}{l}\text { Frame } \\
\text { Marker }\end{array}$} & High School & 43 & 46.5 & -3.5 & .527 & 1 & .468 \\
\hline & American File & 50 & 46.5 & 3.5 & & & \\
\hline & Total & 93 & & & & & \\
\hline \multirow{3}{*}{ Endophoric } & High School & 1 & 1.0 & .0 & .000 & 1 & 1.000 \\
\hline & American File & 1 & 1.0 & .0 & & & \\
\hline & Total & 2 & & & & & \\
\hline \multirow{3}{*}{ Evidential } & High School & 8 & 17.0 & -9.0 & 9.529 & 1 & .002 \\
\hline & American File & 26 & 17.0 & 9.0 & & & \\
\hline & Total & 34 & & & & & \\
\hline \multirow{3}{*}{$\begin{array}{c}\text { Code } \\
\text { Glosses }\end{array}$} & High School & 50 & 40.0 & 10.0 & 5.000 & 1 & .025 \\
\hline & American File & 30 & 40.0 & -10.0 & & & \\
\hline & Total & 80 & & & & & \\
\hline
\end{tabular}

According to Table 12, there were significant differences in the use of evidentials and code glosses among different types of interactive metadiscourse markers in the four textbooks series. As could be observed form this table, the findings provide support for a statistically considerable difference in the proportion of evidentials in the reading sections of American English File series $\left(\chi^{2}=9.529, \mathrm{df}=1, p<0.001\right)$. While, there is a considerable difference in the proportion of code glosses in the reading sections of Iranian English high school textbooks $\left(\chi^{2}=5.000\right.$, df $\left.=1, p<0.001\right)$. The results also revealed that there was no significant difference in the use of transitions $\left(\chi^{2}=0.774, \mathrm{df}=1, p>0.05\right)$, frame markers $\left(\chi^{2}=0.527, \mathrm{df}=1, p>0.05\right)$, and endophorics $\left(\chi^{2}=0.000, \mathrm{df}=1\right.$, $p>0.05)$.

\section{Table 13}

Chi-square Test for Different Types of Interactional metadiscourse in the English Book 3 and American English File Book 3

\begin{tabular}{|c|c|c|c|c|c|c|c|}
\hline Book & & Observed N & Expected N & Residual & Chi-Square & df & Asymp. Sig. \\
\hline \multirow{3}{*}{ Hedges } & High School & 18 & 20.0 & -2.0 & .400 & 1 & .527 \\
\hline & American File & 22 & 20.0 & 2.0 & & & \\
\hline & Total & 40 & & & & & \\
\hline \multirow{3}{*}{ Boosters } & High School & 16 & 15.5 & .5 & .032 & 1 & .857 \\
\hline & American File & 15 & 15.5 & -.5 & & & \\
\hline & Total & 31 & & & & & \\
\hline \multirow{3}{*}{$\begin{array}{l}\text { Attitude } \\
\text { marker }\end{array}$} & High School & 11 & 11.5 & -.5 & .043 & 1 & .835 \\
\hline & American File & 12 & 11.5 & .5 & & & \\
\hline & Total & 23 & & & & & \\
\hline \multirow{3}{*}{$\begin{array}{c}\text { Self- } \\
\text { Mention }\end{array}$} & High School & 1 & 64.5 & -63.5 & 125.031 & 1 & $<.001$ \\
\hline & American File & 128 & 64.5 & 63.5 & & & \\
\hline & Total & 129 & & & & & \\
\hline \multirow{3}{*}{$\begin{array}{l}\text { Engagement } \\
\text { Marker }\end{array}$} & High School & 33 & 24.5 & 8.5 & 5.898 & 1 & .015 \\
\hline & American File & 16 & 24.5 & -8.5 & & & \\
\hline & Total & 49 & & & & & \\
\hline
\end{tabular}


Bagherfard, F., \& Simin, S.

As Table 13 shows, there was significant difference in the use of self-mentions $\left(\chi^{2}=5.898\right.$, df $\left.=1, p<0.05\right)$ among different types of interactional metadiscourse markers in English Book 3 and American English File Book 3. It was evident from the results that the frequency of occurrence of self-mentions in the English Book3 was higher than American English File Book 3. However, it was revealed that there was significant difference in terms of using engagement markers in English Book3. According to this table, two series of textbooks were not statistically different in terms of use of hedges $\left(\chi^{2}=0.400, \mathrm{df}=1, p>0.05\right)$, boosters $\left(\chi^{2}=0.032, \mathrm{df}=1, p>0.05\right)$, and attitude markers $\left(\chi^{2}=0.43, \mathrm{df}=1, p>0.05\right)$.

\section{Table 14}

Chi-square Test for Different Types of Interactional Metadiscourse in the English Book 4 and American English File Book 4

\begin{tabular}{|c|c|c|c|c|c|c|c|}
\hline Book & & Observed N & Expected $\mathrm{N}$ & Residual & Chi-Square & $\mathrm{df}$ & Asymp. Sig. \\
\hline \multirow{3}{*}{ Hedges } & High School & 97 & 97.5 & -.5 & .005 & 1 & .943 \\
\hline & American File & 98 & 97.5 & .5 & & & \\
\hline & Total & 195 & & & & & \\
\hline \multirow{3}{*}{ Boosters } & High School & 32 & 36.0 & -4.0 & .889 & 1 & .346 \\
\hline & American File & 40 & 36.0 & 4.0 & & & \\
\hline & Total & 72 & & & & & \\
\hline \multirow{3}{*}{$\begin{array}{l}\text { Attitude } \\
\text { marker }\end{array}$} & High School & 16 & 17.0 & -1.0 & .118 & 1 & .732 \\
\hline & American File & 18 & 17.0 & 1.0 & & & \\
\hline & Total & 34 & & & & & \\
\hline \multirow{3}{*}{$\begin{array}{c}\text { Self- } \\
\text { Mention }\end{array}$} & High School & 1 & 46.0 & -45.0 & 88.043 & 1 & $<.001$ \\
\hline & American File & 91 & 46.0 & 45.0 & & & \\
\hline & Total & 92 & & & & & \\
\hline \multirow{3}{*}{$\begin{array}{c}\text { Engagement } \\
\text { Marker }\end{array}$} & High School & 164 & 114.5 & 49.5 & 42.799 & 1 & $<.001$ \\
\hline & American File & 65 & 114.5 & -49.5 & & & \\
\hline & Total & 229 & & & & & \\
\hline
\end{tabular}

Chi-square reported in Table 14, revealed that there was significant difference between the English Book 4 and American English File Book 4 in terms of using self-mentions and engagement markers. As could be observed from the table, there was considerable difference in the proportion of self-mentions $\left(\chi^{2}=88.043\right.$, df $=1$, $p<0.001)$ in the American English File Book 4 and in the proportion of engagement markers $\left(\chi^{2}=42.799, \mathrm{df}=1\right.$, $p<0.05)$ in the English Book 4. The results also showed that there was no significant difference in the use of hedges $\left(\chi^{2}=0.005\right.$, df $\left.=1, p>0.05\right)$, boosters $\left(\chi^{2}=0.889, \mathrm{df}=1, p>0.05\right)$, and attitude markers $\left(\chi^{2}=0.118, \mathrm{df}=1\right.$, $p>0.05)$ in two textbook series.

\section{Table 15}

Chi-square Test for Different Types of Interactional metadiscourse in the Four Textbooks

\begin{tabular}{|c|c|c|c|c|c|c|c|}
\hline Book & & Observed N & Expected N & Residual & Chi-Square & df & Asymp. Sig. \\
\hline \multirow{3}{*}{ Hedges } & High School & 115 & 117.5 & -2.5 & .106 & 1 & .744 \\
\hline & American File & 120 & 117.5 & 2.5 & & & \\
\hline & Total & 235 & & & & & \\
\hline \multirow{3}{*}{ Boosters } & High School & 48 & 51.5 & -3.5 & .476 & 1 & .490 \\
\hline & American File & 55 & 51.5 & 3.5 & & & \\
\hline & Total & 103 & & & & & \\
\hline \multirow{3}{*}{$\begin{array}{l}\text { Attitude } \\
\text { marker }\end{array}$} & High School & 27 & 28.5 & -1.5 & .158 & 1 & .691 \\
\hline & American File & 30 & 28.5 & 1.5 & & & \\
\hline & Total & 57 & & & & & \\
\hline \multirow{3}{*}{$\begin{array}{c}\text { Self- } \\
\text { Mention }\end{array}$} & High School & 2 & 110.5 & -108.5 & 213.072 & 1 & $<.001$ \\
\hline & American File & 219 & 110.5 & 108.5 & & & \\
\hline & Total & 221 & & & & & \\
\hline \multirow{3}{*}{$\begin{array}{c}\text { Engagement } \\
\text { Marker }\end{array}$} & High School & 197 & 139.0 & 58.0 & 48.403 & 1 & $<.001$ \\
\hline & American File & 81 & 139.0 & -58.0 & & & \\
\hline & Total & 278 & & & & & \\
\hline
\end{tabular}


The results in Table 15 showed that the significance level was $\left(\chi^{2}=213.072, \mathrm{df}=1, p<0.001\right)$ for the self-mentions which indicated that there were significant differences between Iranian high school textbooks and American English File book series in terms of using self-mentions. However, based on findings, there was a significant difference in the use of engagement markers $\left(\chi^{2}=48.403, \mathrm{df}=1, p<0.05\right)$ between two series. It means that Iranian high school textbooks applied engagement markers more than American English File book series. According to this table, no statistically significant value was obtained between the two textbooks series in terms of using hedges $\left(\chi^{2}=0.106, \mathrm{df}=1, p>0.05\right)$, boosters $\left(\chi^{2}=0.476, \mathrm{df}=1, p>0.05\right)$, and attitude markers $\left(\chi^{2}=0.158\right.$, $\mathrm{df}=1, p>0.05)$.

\section{Discussions}

Based on the obtained results, there are some similarities and differences between Iranian high school English textbooks and American English File series in using interactive and interactional metadiscourse markers. With regard to the first research question, the findings showed that, the occurrence of interactive metadiscourse markers in the Iranian high school textbooks (55.5\%) was generally more than the American English File series (48.0\%). More specifically, from among interactive metadiscourse markers, transitions were the most frequent markers used in two textbook series. This might be due to the fact that transitions are mainly used to help readers interpret the links between ideas in a text. They also are employed to guide the reader through the propositions and build the concept in the mind of the writer (Thompson, 2001). After transitions, frame markers (10.7\%), code glosses $(6.5 \%)$, and evidentials $(5.6 \%)$ were respectively the most frequent interactive metadiscourse markers in American English File series. In Iranian high school English textbooks, after transitions, code glosses $(10.3 \%)$, frame markers $(8.8 \%)$, and evidentials $(1.6 \%)$ were respectively the most frequent interactive metadiscourse markers in American English File series. The use of endophorics in two corpora was the same. The results of study revealed that interactional metadiscourse markers were used more than interactive ones in American English File series with frequencies of (52\%) and (44.0\%) respectively. From among interactional markers, self- mentions (43.4\%) were used more than other markers in American English File series. After self-mentions, hedges (23.8\%), engagement markers (16.0\%), boosters (10.9\%), and attitude markers (5.9\%) were respectively the most frequent metadiscourse markers in this corpus. Among interactional markers, in Iranian high school textbooks, engagement markers (50.0\%) were used as most proportion. The other interactional markers such as hedges (29.6\%), boosters (12.3\%), attitude markers (6.9\%), and self-mentions $(0.3 \%)$ were respectively the most frequent markers in the corpus.

Regarding the second research question, the findings revealed that there were significant differences between Iranian high school textbooks and American English File series in terms of using interactional metadiscourse markers. But there were not any significant differences between these two textbooks in terms of applying interactive metadiscourse. The results of the study indicated that there was a statistically significant difference between two corpora in the use of evidentials. Therefore, evidentials were used more frequently by American English File series than Iranian high school textbooks. It indicates that American English File series tend to refer to information from other texts. There was also a statistically significant difference between two textbook series in the use of code glosses. It implies that code glosses are used more frequently by Iranian high school textbooks than their counterpart. In other words, high school textbooks applied exemplification and reformulation more than American English File series to elaborate the propositional meaning. Considering interactional metadiscourse, there were significant differences in the use of self-mentions and engagement markers in two series of textbooks. Thus, self-mentions were used more frequently by American English File series than Iranian high school textbooks. It shows that American English File series attempted to use personal voice more than the other textbooks. There was also significant difference between these two textbook series in the use of engagement markers. The greater use of engagement markers in high school textbooks indicates that Iranian authors attempted to address their readers or engage them as discourse participant in the reading sections of these textbooks.

The present findings are contrary to the previous study (Alemi \& Isavi, 2012) which have reported that self- 
mentions were the most common interactional type in $I L I$ series and engagement markers dominate in Top-Notch series, but our findings showed among the different categories of interactional metadiscourse markers, engagement markers seem to have the highest frequency of use in the high school textbooks and self-mentions have the greatest frequency of use in American English File series.

The result of this study is consistent with the findings of Shokhouhi and Talati Baghsiahi (2009) which found a higher number of metadiscourse elements in the English texts. Totally, interactive metadiscourse was used more than interactional metadiscourse by Iranian high school textbooks. In these two textbooks transitions were the most frequent markers. This is in line with Rahimpour (2006)'s findings.

\section{Conclusion}

In this study, the results showed that both corpora employed interactive and interactional metadiscourse markers in their reading sections. However, Iranian authors used more interactive metadiscouse markers in the reading sections of the Iranian high school textbooks; conversely, English authors applied more interactional metadiscourse in the reading sections of American English File series. The statistical analysis of the results showed that there were significant differences between the two ELT textbooks in terms of applying interactional metadiscoure markers but differences were not significant in terms of using interactive metadiscourse in two textbook series. Moreover, the observation was that there were significant differences on the particular occurrence of some categories in interactive and interactional metadiscourse markers. The use of transitions and code glosses in Iranian high school textbooks was higher than that of American English File books, whereas English authors used frame markers and evidentials more than their English counterparts. The findings showed significant differences in the use of code glosses and evidentials. In the case of interactional metadiscourse, there were significant differences in terms of applying engagement markers and self- mentions. It can be concluded, the differences among the frequencies and types of metadiscourse markers in these two ELT textbooks maybe are due to their cultural differences. As stated by Hyland (2004) the writer's cultural and linguistic preferences can affect the use of metadiscourse markers in the texts.

\subsection{Implications of the Study}

The findings of the present study can be beneficial for curriculum and syllabus designers. They should be aware of using appropriate interactive and interactional metadiscourse markers in ELT textbooks. Additionally, the findings of this study can be important for teachers in guiding and encouraging students to apply these metadiscourse markers in their writing appropriately since as noted by Simin and Tavangar (2009) "focusing on grammar and sentence structure alone is not the key to making better EFL/ESL student writer" (pp. 245-246). This study also can help foreign language authors produce texts that are useful and reader- based. The finding of this research would help material developers to keep aware of these linguistic elements. Moreover, the results would assist instructors use more effective teaching methodologies which integrate specific instruction related to metadiscourse markers in order to take into consideration to the better criteria for developing appropriate materials. As metadiscourse markers can help students in understanding and writing different texts and since, it is necessary to familiarize the learners with metadiscourse markers and their functions in the texts, the results can be beneficial for teachers to teach these metadiscourse markers to students.

\section{References}

Ädel, A. (2006). Metadsicourse in L1 and L2 English. Amsterdam: John Benjamins. http://dx.doi.org/10.1075/scl.24

Alavinia, P., \& Siyadat, M. (2013). A comparative study of English textbooks used in Iranian institutes. International Journal of Asian Social Science, 3(1), 150-170.

Albaz-Juez, L. (2009). Perspectives on discourse analysis: theory and practice. Cambridge Scholars Publishing. Alemi, M., \& Isavi, E. (2012). Evaluation of interactional metadiscourse in EFL textbooks. Advances in Asian 
Comparative of metadiscourse markers in ELT textbooks and Iranian localized high school English textbooks

Social Science, 2(1), 422-430.

Birjandi, P., Ananisarab, M. R., \& Samimi, D. (2013). Learning to read English for pre-university students. Tehran: Iran: Textbook Publisher.

Birjandi, P., Nowruzi, M., \& Mahmoodi, Gh. H. (2013). English book 3. Tehran: Iran Publication.

Flesch, R. (1948). A new readability yardstick. Journal of Applied Psychology, 32, 221-223. http://dx.doi.org/10.1037/h0057532

Hyland, K. (2000). Disciplinary discourse: Social interactions in academic writing. Harlow UK: Longman.

Hyland, K. (2004). Disciplinary interactions: Metadiscourse in L2 postgraduate writing. Journal of Second Language Writing, 13, 133-151. http://dx.doi.org/10.1016/j.jslw.2004.02.001

Hyland, K. (2005). Metadiscourse: Exploring interaction in writing. London: Continuum.

Jahangard, A. (2007). Evaluation of EFL materials taught at Iranian public high schools. Asian EFL Journal, $9(2), 130-150$.

Littlejohn, A. (2011). The analysis of language teaching materials: Inside the Trojan Horse. In B. Tomlinson (Ed.), Materials development in language teaching (pp. 179-211). Cambridge: Cambridge University Press.

McDonough, J., \& Shaw, C. (2003). Materials and methodology in ELT: A teacher's guide. Malden, MA: Blackwell Publishing.

McGrath, I. (2002). Materials evaluation and design for language teaching. Edinburgh, Edinburgh University Press.

Oxenden, C. \& Latham-Koening, Ch. (2013). American English File Student Book 3 (second edition). Oxford: Oxford University Press.

Oxenden, C. \& Latham-Koening, Ch. (2013). American English File Student Book 4 (second edition). Oxford: Oxford University Press.

Rahimpour, S. (2006). Contrastive rhetoric of English and Persian texts; Metadiscourse in applied linguistics research articles (Unpublished masteral thesis). University of Mashhad.

Riazi, M., \& Mosalanejad, N. (2010). Evaluation of learning objectives in Iranian high-school and pre-university English textbooks using Bloom's taxonomy. The Electronic Journal for English as a Second Language, 13(4), 1-16.

Richard, C. (2006). Developing classroom speaking activities: From theory to practice. British library direct, $28(2), 3-8$.

Richards, J. C. (2001). Curriculum development in language teaching. New York: Cambridge University Press. http://dx.doi.org/10.1017/CBO9780511667220

Shokouhi, H., \& Talati Baghsiahi, A. (2009) Metadiscourse functions in English and Persian sociology articles: a study in contrastive rhetoric. Poznan Studies in Contemporary Linguistics, 45(4), 549-568. http://dx.doi.org/10.2478/v10010-009-0026-2

Simin, Sh., \& Tavangar, M. (2009). Metadiscourse knowledge and use in Iranian EFL writing. Asian EFL Journal, 11(1), 230-255.

Taki, S. (2004). A critical study of ideological import of locally and internationally developed ELT materials (Unpublished doctoral dissertation). University of Isfahan, Iran.

Talebinezhad, M. R., \& Namdar, A. (2011). Discourse markers in high school English textbooks in Iran. Theory and Practice in Language Studies, 1(11), 1590-1602. http://dx.doi.org/10.4304/tpls.1.11.1590-1602

Thompson, S. E. (2003). Text-structuring metadiscourse, intonation and the signaling of organization in academic lectures. Journal of English for Academic Purposes, 2, 5-20.

http://dx.doi.org/10.1016/S1475-1585(02)00036-X

Tomlinson, B. (2001). Materials development. In R. Carter \& D. Nunan (Ed.), The Cambridge guide to teaching. English to speakers of other languages (pp. 66-71). Cambridge: Cambridge University Press. http://dx.doi.org/10.1017/CBO9780511667206.010

Vande Kopple, W. J. (2002). Metadiscourse, discourse, and issues in composition and rhetoric. In Barton \& G. Stygall (Eds.), Discourse studies in composition (pp. 91-113). Cresskill, NJ: Hampton Press.

Waters, A. (2009). Advances in materials design. In M. Long \& C. J. Doughty (Eds.), The handbook of language 
Bagherfard, F., \& Simin, S.

teaching (pp. 311-326). West Sussex: Wiley-Blackwell. http://dx.doi.org/10.1002/9781444315783.ch18

Zohrabi, M., Sabouri, H., \& Kheradmand, M. (2014). Comparative study of Interchange1 and English book1 of Iranian high schools. Education International Journal of English, 3(2), 95-104. 